\title{
Movements and distribution of northern bottlenose whales, Hyperoodon ampullatus, on the Scotian Slope and in adjacent waters
}

\author{
Tonya Wimmer and Hal Whitehead
}

\begin{abstract}
A small, apparently isolated, and endangered population of 130 northern bottlenose whales (Hyperoodon ampullatus Forster, 1770) is found on the Scotian Slope south of Nova Scotia, Canada. Virtually all previous information on these animals had come from the Gully, a large submarine canyon where the northern bottlenose whales can be reliably found. A ship survey along the $1000 \mathrm{~m}$ depth contour in 2001 showed northern bottlenose whales only in the Gully, Shortland canyon (50 km east of the Gully), and Haldimand canyon (100 km east of the Gully). Studies in 2002 reconfirmed the presence of the whales in these other canyons, although densities were about $50 \%$ lower than in the Gully. Photo-identifications showed that individuals moved between the Gully and Shortland and Haldimand canyons over periods from days to years, with mean stays in any canyon of about 22 days. However, the population was not fully mixed: at least some individuals had preferences for particular canyons. The sex ratios were similar in all canyons, but males had higher rates of movement between canyons. These results are consistent with the expectations of optimal foraging theory, when the primary resource for females, deep-water squid of the genus Gonatus Gray, 1849, is more temporally stable than the primary resource for males, which is assumed to be receptive females. Haldimand and Shortland canyons are clearly important habitat for this species, and should receive appropriate protection.
\end{abstract}

Résumé : Une petite population apparemment isolée et menacée de 130 baleines à bec communes (Hyperoodon ampullatus Forster, 1770) se retrouve sur le talus continental néo-écossais, au sud de la Nouvelle-Écosse, Canada. Presque toute l'information antérieure sur ces animaux provient de la région du Gully, un grand canyon sous-marin où les baleines à bec communes peuvent être trouvées régulièrement. Un inventaire en bateau le long du contour de $1000 \mathrm{~m}$ en 2001 a révélé la présence de baleines à bec communes seulement dans le Gully, dans le canyon Shortland (50 km à l'est du Gully) et dans le canyon Haldimand (100 km à l'est du Gully). Des études en 2002 confirment la présence des baleines dans les deux autres canyons, bien que les densités y soient d'environ $50 \%$ plus basses que dans le Gully. Les identifications de baleines à l'aide de photographies indiquent que les individus se déplacent entre le Gully et les canyons Shortland et Haldimand sur des périodes variant de quelques jours à quelques années avec des durées moyennes de séjour dans un même canyon d'environ 22 jours. La population n'est cependant pas totalement intégrée et au moins quelques individus montrent une préférence pour un canyon en particulier. Le rapport mâles:femelles est semblable dans tous les canyons, mais les mâles ont un plus fort taux de déplacement d'un canyon à un autre. Ces résultats s'accordent avec les prédictions de la théorie de la quête optimale lorsque la ressource principale pour les femelles, les calmars d'eau profonde (genre Gonatus Gray, 1849), est plus stable dans le temps que celle des mâles qu'on assume être des femelles réceptives. Les canyons Haldimand et Shortland sont de toute évidence des habitats importants pour l'espèce et devraient donc jouir d'une protection appropriée.

[Traduit par la Rédaction]

\section{Introduction}

Patterns of distribution and movement must be examined to understand how an organism relates to its abiotic, biotic, and social environments (Turchin 1998; Whitehead 2001). Movement and distribution patterns also have a major influence on population structure and thus are often significant

Received 3 May 2004. Accepted 25 November 2004.

Published on the NRC Research Press Web site at http://cjz.nrc.ca on 4 February 2005.

T. Wimmer ${ }^{1}$ and H. Whitehead. Department of Biology, Dalhousie University, Halifax, NS B3H 4J1, Canada.

${ }^{1}$ Corresponding author (e-mail: twimmer@dal.ca). components of management and conservation initiatives (e.g., O'Corry-Crowe et al. 1997; Read and Westgate 1997).

For the northern bottlenose whale (Hyperoodon ampullatus Forster, 1770), a 7-9 m long beaked whale of northern North Atlantic waters, gaps in our knowledge of distribution and movement have been a particular problem over the last few years. A population of about 130 of these animals uses the waters of the Scotian Slope south of Nova Scotia (Gowans et al. 2000b), but virtually all the available information on these animals comes from one location, a large submarine canyon called the Gully (Fig. 1). Studies within the Gully have suggested that for large pelagic animals, these animals have remarkably restricted movement patterns (Hooker et al. 2002b), but that only about 34\% of the population is in the Gully at any time (Gowans et al. 2000b). From the purely biological perspective of investigating this 
Fig. 1. Northern bottlenose whale (Hyperoodon ampullatus) sightings off the northeast USA and eastern Canada. Sightings were compiled from Canada Department of Fisheries and Oceans (DFO) Newfoundland ( $\otimes$ ), DFO-Maritimes (shaded squares), SPANS oil and gas observer program $(\boldsymbol{\Delta})$, R. Kenney (shaded circles), and a report of an entangled whale (†). Reported northern bottlenose whale strandings are also shown ( $\star$ ). The Hague Line (HL), Northeast Channel (NC), Scotian Shelf, Laurentian Channel (LC), and Grand Banks are also shown. The scale bar represents $280 \mathrm{~km}$.

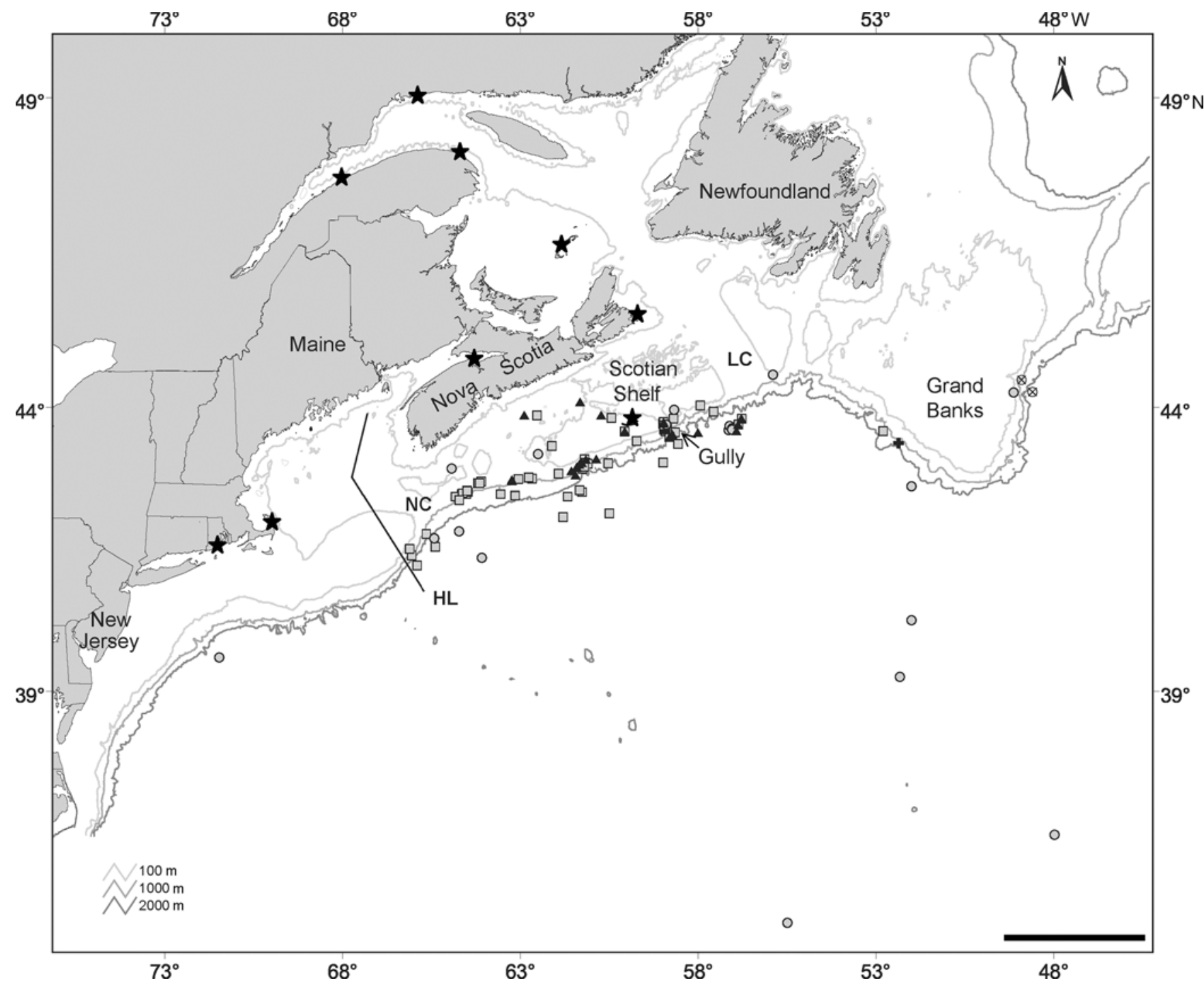

apparently unusual ranging behaviour, it was important to determine where the animals are when they are not in the Gully.

This knowledge is also important for conservation. Oil and gas exploration and development is expanding rapidly on the Scotian Shelf and Scotian Slope. Several activities associated with this exploration and development, such as the loud sounds of seismic surveying, are of concern for northern bottlenose whales (e.g., see Houser et al. 2001). Typically, several seismic programs are carried out per year. Deep divers, and perhaps especially the beaked whales, are thought to be particularly susceptible to loud sounds (Houser et al. 2001; International Whaling Commission 2004). Although the Gully is effectively protected from petrochemical activities because it was established as the Gully Marine Protected Area in 2004, the canyon is almost ringed with oil and gas leases (Canada - Nova Scotia Offshore Petroleum
Board 2004). Sounds made outside the Gully enter it, and the animals may be threatened when they leave it. The level of this threat, as well as that posed by entanglement in fishing gear (Gowans et al. 2000b), clearly depends on the distribution and movements of northern bottlenose whales when they are outside the Gully. Concerns about these threats, together with the small size of the population, led to the population being declared endangered by the Committee on the Status of Endangered Wildlife (COSEWIC) in Canada in 2002 (Committee on the Status of Endangered Wildlife 2002).

Genetic analyses (Dalebout et al. 2001) and other data (Whitehead et al. 1997) suggest that there is little, if any, interchange between the northern bottlenose whales in the Gully and those in the nearest other population centre, off northern Labrador. Information on the distribution of northern bottlenose whales in the Gully and elsewhere in the 
North Atlantic Ocean (Reeves et al. 1993; Hooker et al. $2002 b$ ), as well as the distribution of their major prey, squid of the genus Gonatus Gray, 1849, (Bjørke 2001), all suggests that these animals are primarily found in water approximately $1000 \mathrm{~m}$ deep. Thus, it is likely that some Gully northern bottlenose whales distribute themselves along the $1000 \mathrm{~m}$ depth contour at least some of the time when they are not in the Gully.

In this paper we will $(i)$ investigate the known distribution of northern bottlenose whales on the Scotian Slope (the waters between the 200 and $4000 \mathrm{~m}$ depth contours south of Nova Scotia) and in adjacent waters; (ii) determine whether there are locations in this area, other than the Gully, where northern bottlenose whales consistently concentrate; and (iii) develop models describing the movements of Scotian Slope northern bottlenose whales.

\section{Methods}

\section{Distributional records}

We searched the published and unpublished literature, databases, fisheries observer reports, reports of dedicated surveys, and opportunistic sightings for records of northern bottlenose whales between longitudes $72^{\circ}$ and $54^{\circ} \mathrm{W}$ (New Jersey to the southern Grand Banks off Newfoundland). We know of no sightings west of $72^{\circ} \mathrm{W}$, and sightings between the Grand Banks and the waters off northern Labrador are few (Reeves et al. 1993).

\section{Fieldwork}

In 2001 we surveyed the waters along the $1000 \mathrm{~m}$ depth contour between latitudes $54^{\circ}$ and $72^{\circ} \mathrm{W}$ using a $12.5-\mathrm{m}$ ocean-going auxiliary cutter. The survey was partitioned into four geographical areas: New Jersey - Hague Line (USCanada border), Hague Line - Northeast Channel, Scotian Shelf, and Laurentian Channel - Grand Banks. Surveys were conducted only during the daytime, and only in reasonably good weather conditions (Beaufort sea state <5). Vessel speed varied between 1 and $6 \mathrm{kn}$. In total, $2061 \mathrm{~km}$ was surveyed over a period of 257 search hours. There was a gap in surveying (due to bad weather) between $66^{\circ}$ and $70^{\circ} \mathrm{W}$.

The 2001 surveys indicated that Shortland and Haldimand canyons may be important habitat for northern bottlenose whales. In 2002, these canyons, together with the Gully, were surveyed for northern bottlenose whales during two 3week trips. The sampling design was to spend 2 days (of Beaufort sea state $<5$ ) in one canyon before switching to another canyon, and so on (for details of dates, etc., see Wimmer 2003).

During both 2001 and 2002, two observers searched for cetaceans using the unaided eye during daylight hours, weather permitting (i.e., little rain or fog, Beaufort sea state $<5)$. One observer was at the helm and another either on the foredeck or $10 \mathrm{~m}$ up the mast in the crow's nest (only in Beaufort <4). For each sighting of northern bottlenose whales, the approximate group size, time, and location (from a Garmin 65 GPS Global Navigator) were recorded.

Northern bottlenose whales were approached to within $30 \mathrm{~m}$, and photographs were taken of the dorsal fin and surrounding flank area for photo-identification (Gowans and Whitehead 2001), as well as the melon (forehead) for gender determination (Gowans et al. 2000a), using a Canon EOS 35-mm camera, 300-mm lens, and black-and-white Ilford HP5 film. Whenever possible, photographs were taken from both left and right sides of the dorsal fin.

Digital photographs of northern bottlenose whales were also collected by S.K. Hooker during the National Marine Fisheries Service (NMFS) Large Whale Survey cruise on 8 and 14 August 2002. Here, northern bottlenose whales were approached to within $20 \mathrm{~m}$ using inflatable outboardpowered vessels.

\section{Photo-identification}

Black-and-white negatives and digital photographs were examined and a quality $(Q)$ value from 1 (low) to 6 (high) was assigned based on focus, exposure, angle of fin relative to the negative plane, and proportion of the frame filled by the fin (Gowans and Whitehead 2001). The highest quality negative of each individual in each year was printed and compared with the other photographs from that year and previous years in the existing catalogue (Gowans and Whitehead 2001). Wherever possible, individuals were assigned to one of three age-sex classes based upon the shape of the melon: mature male, subadult male, or female / immature male (Gray 1882; Gowans et al. 2000a).

Gowans and Whitehead (2001) concluded that all members of the population possess sufficient dorsal-fin markings that they can be reidentified from high-quality photographs over periods of less than a few months, whereas only $66 \%$ of this population possess marks that persist for periods of years, i.e., are "reliably marked". Thus, for time scales greater than 1 year, only reliably marked individuals with good-quality photographs $(Q>3)$ were included in the analyses. For time scales shorter than this, all identifications of all individuals from photographs with $Q>2$ were used.

\section{Analyses}

The rate of encounter with northern bottlenose whales within each canyon was calculated as the number of encounters with northern bottlenose whales divided by the number of hours spent searching when conditions were good (daylight hours from 0600 to 2100 , Beaufort sea state $<5$, visibility $>500 \mathrm{~m}$ ). An encounter began when whales were first sighted and ended when whales had not been observed for at least $10 \mathrm{~min}$.

To determine whether the population was fully mixing within all canyons, a $G$ test for goodness of fit was used. If there was full mixing of individuals within the three canyons, individuals identified prior to 2000 in the Gully would be just as likely to be seen in any of the three canyons as those not previously identified in the Gully.

A $G$ test for goodness of fit was also used to test the null hypothesis that the probability of an animal being identified in a particular canyon was independent of its age-sex class.

The overall residence time of individuals within canyons was investigated by calculating the lagged identification rate (LIR) using the "Movement" module of SOCPROG version 2.0 (Whitehead 2004). The LIR is the probability that if an animal is identified in the area at any time, it will be identified during any single identification made in the area after a certain time lag (Whitehead 2001):

$$
R(\tau)=P(\tau) / N
$$


where $R(\tau)$ is the LIR for time lag $\tau ; P(\tau)$ is the probability that the individual is still in the study area after time lag $\tau$; and $N$ is the population size in the study area.

LIRs were estimated by

$$
\hat{R}(\tau)=\frac{\sum_{i} \sum_{j: t_{j}=t_{i}+\tau} m_{i j}}{\sum_{i} n_{i} \sum_{j: t_{j}=t_{i}+\tau} n_{j}}
$$

where $n_{i}$ is the individual identified at time $t_{i} ; m_{i j}$ is the number of individuals identified at both time $t_{i}$ and time $t_{j}$.

For this analysis, photo-identification data collected during 2001/2002 for the three canyons were added to the existing photo-identification data set (collected within the Gully from 1988 to 1999). The maximum time lag $(\tau)$ between photographs considered was 100 days, which is longer than the number of days in a field season but less than that between field seasons. Thus, all individuals, not just reliably marked individuals, were included in the analysis, as marks were unlikely to have changed significantly within 100 days (Gowans and Whitehead 2001). Very few births or deaths were likely to occur during the 100-day sampling period, therefore mortality and birth rates were considered to be zero. Three models of residency were fitted to the identificationrate data, using likelihood methods (Whitehead 2001):

(1) "closed" (no changes in the individuals present in a study area):

$$
R(\tau)=\left(\frac{1}{N}\right)
$$

(2) "emigration" (individuals leave a study area but never return):

$$
R(\tau)=\left(\frac{1}{N}\right) \mathrm{e}^{-\tau / I}
$$

(3) "emigration and re-immigration" (individuals leave a study area and then re-enter it):

$$
R(\tau)=\frac{O \mathrm{e}^{-\tau(1 / O+1 / I)}+I}{(I+O) N}
$$

where $N$ is the number of individuals in a study area; $I$ is the mean time spent inside a study area; and $O$ is the mean time spent outside a study area.

The LIR can be extended to include more than one study area (Whitehead 2001). In this case the LIR is the probability that if an animal is identified in one area at any time, it is identified during any single identification made in another area after a certain time lag (Whitehead 2001). Again, the maximum time lag considered was 100 days, thus all photographs with $Q>2$ were used in the analysis. Two models were fitted to between-canyon LIRs:

(4) "fully mixed" (individuals are moving randomly among study areas at rates sufficiently fast that there is full mixing within one time unit):

$$
R(\tau)=\left(\frac{1}{N}\right)
$$

(5) "migration - full interchange" (individuals are moving randomly among study areas, spending the same mean time in each before moving on):

$$
R(\tau)=\left(\frac{1}{N}\right)\left(1-\mathrm{e}^{-\tau / I}\right)
$$

where $N$ is the population size in any study area during a time unit and $I$ is the mean residence time in a study area.

For these analyses, only the identifications from 2001 and 2002 were useful, as these were the only years in which studies were carried out in more than one canyon.

In both analyses time units were days, and model performance was assessed by comparing summed log-likelihoods (Whitehead 2001).

LIRs were also calculated, and models fitted, for males and females / immature males separately to investigate whether the sexes exhibited different residency patterns and movements between canyons.

Transition probabilities, i.e., the probabilities of moving between four areas (the Gully, Shortland and Haldimand canyons, and some "other" external area) were estimated by means of likelihood methods using the "Movement" module of SOCPROG version 2.0 (Whitehead 2004). An external area was added to the analysis to account for individuals that are not found in any of the three canyons, as it is unlikely that the three canyons support the entire population at a given time. This process uses likelihood methods (Whitehead 2001) to estimate unknown parameters (the transition probabilities between the four areas per day) given the population size (assumed to be 130 animals; Gowans et al. $2000 b$ ). Bootstrapping techniques (resampling data with replacement) were used to estimate standard errors (SE) for each model parameter.

\section{Results}

\section{Distribution of northern bottlenose whales on the Scotian Slope and in adjacent waters}

Previous records of northern bottlenose whales on the Scotian Slope and in adjacent waters are summarized in Table 1 and Fig. 1, excluding the many sightings made in the Gully during research by H. Whitehead, S.K. Hooker, and colleagues (summarized by Hooker et al. 1999, 2002b). General information on northern bottlenose whale distribution was also available from the Sea Education Association, which operates education/research cruises in the study area from Woods Hole, Massachusetts. The principal location in which they have sighted northern bottlenose whales is the Gully (E. Zettler, personal communication).

The southernmost sighting was of two northern bottlenose whales at $39^{\circ} 1.0^{\prime} \mathrm{N}, 72^{\circ} 32.0^{\prime} \mathrm{W}$, off New Jersey, in 1981 , and the easternmost was at $44^{\circ} 28.2^{\prime} \mathrm{N}, 48^{\circ} 34.2^{\prime} \mathrm{W}$, off the Grand Banks, in 1980 (Fig. 1). The majority of the reported sightings were along the shelf edge, although there were some in the deeper waters off the Scotian Shelf. Records of northern bottlenose whales on the Scotian Shelf in waters shallower than $500 \mathrm{~m}$ recorded during observers' programs (Fig. 1) are likely to be misidentifications.

During our survey along the $1000 \mathrm{~m}$ depth contour in 2001 (Fig. 2), northern bottlenose whales were sighted in the Gully and in only two other locations, Shortland and 
Table 1. Numbers of published and unpublished sightings and strandings of northern bottlenose whales (Hyperoodon ampullatus) in various geographical areas off the northeast United States and Canada from 1867 to 2003, showing the certainty of the information.

\begin{tabular}{|c|c|c|c|c|c|}
\hline $\begin{array}{l}\text { New Jersey - } \\
\text { Hague Line }\end{array}$ & $\begin{array}{l}\text { Hague Line - } \\
\text { Northeast Channel }\end{array}$ & $\begin{array}{l}\text { Scotian } \\
\text { Shelf }\end{array}$ & $\begin{array}{l}\text { Laurentian Channel - } \\
\text { Grand Banks }\end{array}$ & $\begin{array}{l}\text { Certainty of } \\
\text { observations }\end{array}$ & Source \\
\hline 0 & 0 & 0 & 2 & Majority certain & G. Stenson, DFO-Newfoundland ${ }^{a}$ \\
\hline 0 & 0 & 0 & 0 & All certain & A. Lock, ${ }^{a}$ PIROP ${ }^{b}$ \\
\hline 2 & 2 & 65 & 3 & Majority uncertain & $\begin{array}{l}\text { J. Conway and S.C. Smith, DFO- } \\
\text { Maritimes }^{a}\end{array}$ \\
\hline 0 & 0 & 0 & 1 & All certain & M. Schowell, DFO-Entanglement ${ }^{a}$ \\
\hline 4 & 0 & 15 & 4 & Majority certain & R. Kenney ${ }^{a, c}$ \\
\hline 1 & 1 & 25 & 0 & All certain & Reeves et al. 1993 and references therein \\
\hline 3 & 3 & 0 & 0 & All certain & Waring et al. 2002 \\
\hline 3 & 3 & 5 & 0 & All certain & S. Hooker 1999 and references therein \\
\hline
\end{tabular}

Note: DFO, Canada Department of Fisheries and Oceans.

${ }^{a}$ Personal communication.

${ }^{b}$ Programme integer de researche sur les oiseaux pélagiques (compiled by the Canadian Wildlife Service, Environment Canada).

${ }^{c}$ Database managed by R. Kenney, University of Rhode Island, compiled from several sources, including the Cetacean and Turtle Assessment Program (1982), naval sightings, and NMFS whale surveys.

Fig. 2. The survey route in 2001 (indicated by the black line). The scale bar represents $280 \mathrm{~km}$.

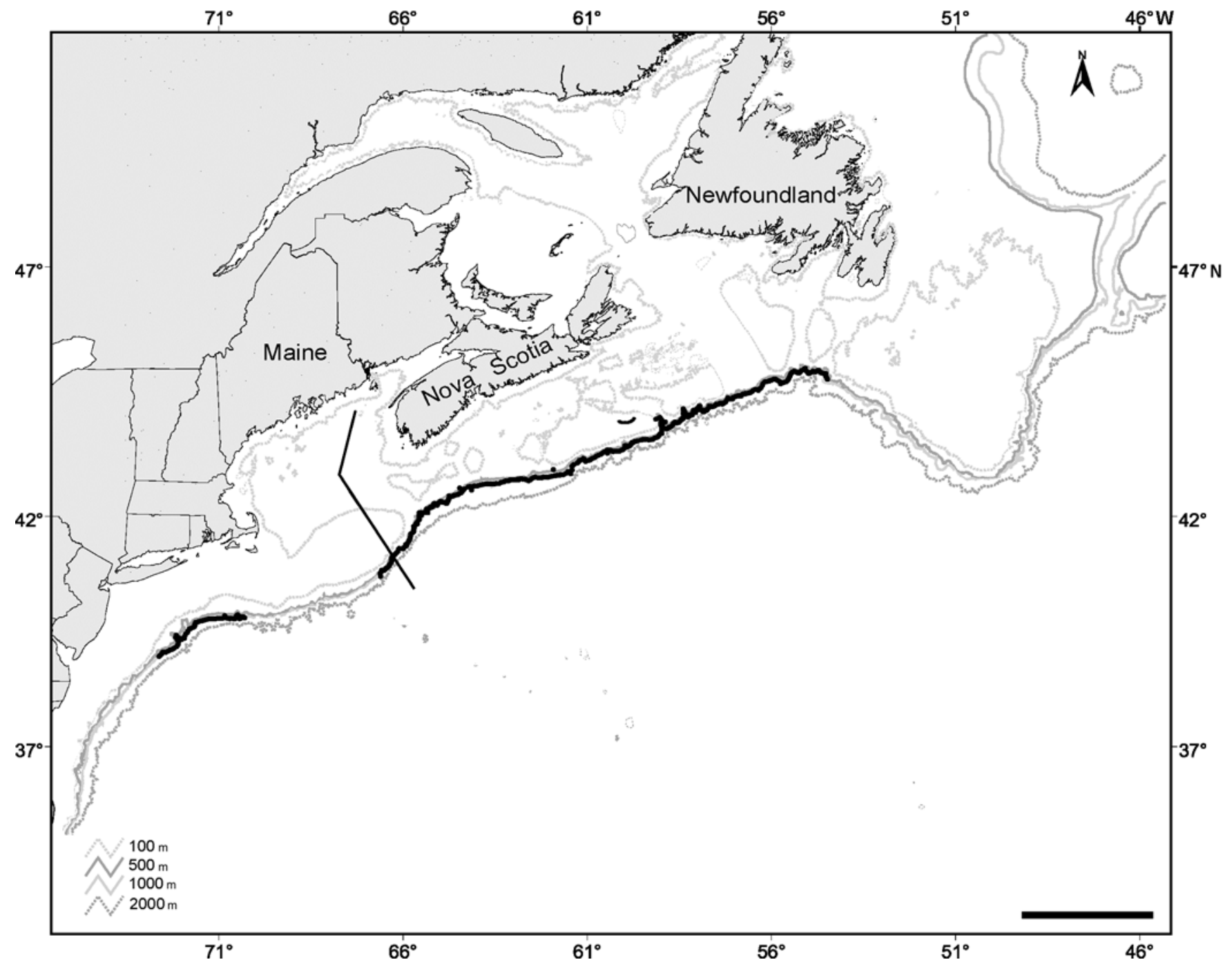


Table 2. Survey effort in each geographical area for 2001.

\begin{tabular}{|c|c|c|c|c|c|}
\hline Geographical area & Longitude range & Dates & $\begin{array}{l}\text { No. of } \\
\text { search } \\
\text { hours }\end{array}$ & $\begin{array}{l}\text { No. of } \\
\text { kilometres } \\
\text { searched }\end{array}$ & $\begin{array}{l}\text { No. of encounters } \\
\text { with northern } \\
\text { bottlenose whales }\end{array}$ \\
\hline New Jersey - Hague Line & $72^{\circ} 40^{\prime}-66^{\circ} 00^{\prime}$ & 17-19 May & 38.4 & 174 & 0 \\
\hline Hague Line - Northeast Channel & $66^{\circ} 00^{\prime}-65^{\circ} 40^{\prime}$ & 22-24 May & 22.4 & 45 & 0 \\
\hline Scotian Shelf & $65^{\circ} 40^{\prime}-57^{\circ} 28^{\prime}$ & $\begin{array}{l}\text { 24-27 May; 28-31 July; 1-13, } \\
\text { 20-21, and 28-29 August }\end{array}$ & 153.9 & 1563 & 16 \\
\hline
\end{tabular}

Fig. 3. Sightings of northern bottlenose whales during the 2001 survey. The scale bar represents $35 \mathrm{~km}$.

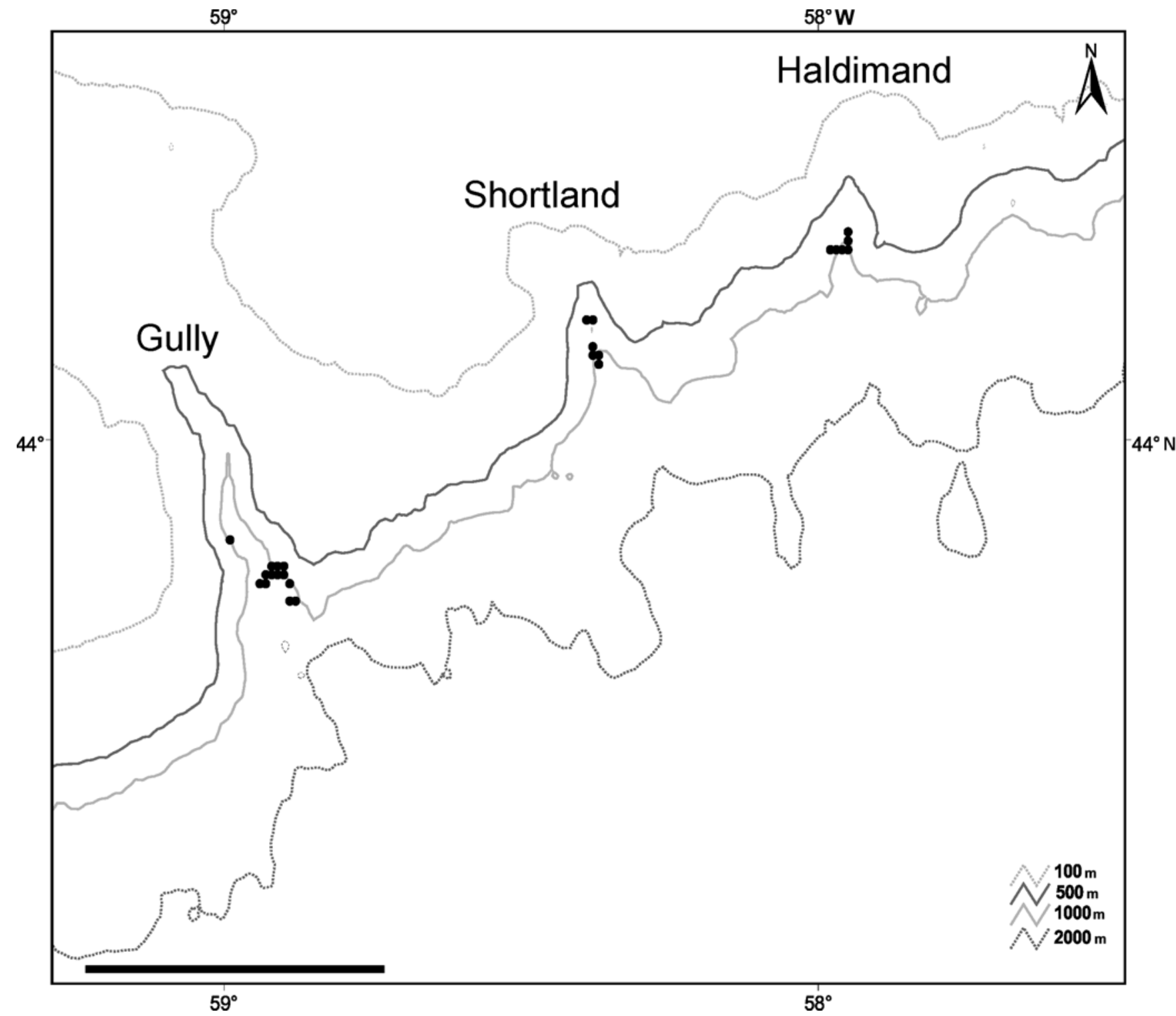

Haldimand canyons, which lie about 50 and $100 \mathrm{~km}$ east of the Gully, respectively (Table 2, Fig. 3). Other cetaceans were frequently sighted right along the transect route (Wimmer 2003), including some like Mesoplodon Gervais, 1850 spp., which are less visible than northern bottlenose whales. Research in 2002 confirmed that northern bottlenose whales regularly use Shortland and Haldimand canyons (Fig. 4).
Northern bottlenose whales were encountered in Shortland and Haldimand canyons at a rate about half that in the Gully (Table 3), which suggests about half the density. However, the distributions of water depths over which the animals were encountered were similar in the three canyons (Figs. 3 and 4, Table 3). The whales seem to prefer waters between about 800 and $1500 \mathrm{~m}$ deep within all three canyons. Figure 5 shows the sightings of all northern bottlenose 
Fig. 4. Sightings of northern bottlenose whales during research in 2002 . The scale bar represents $35 \mathrm{~km}$.

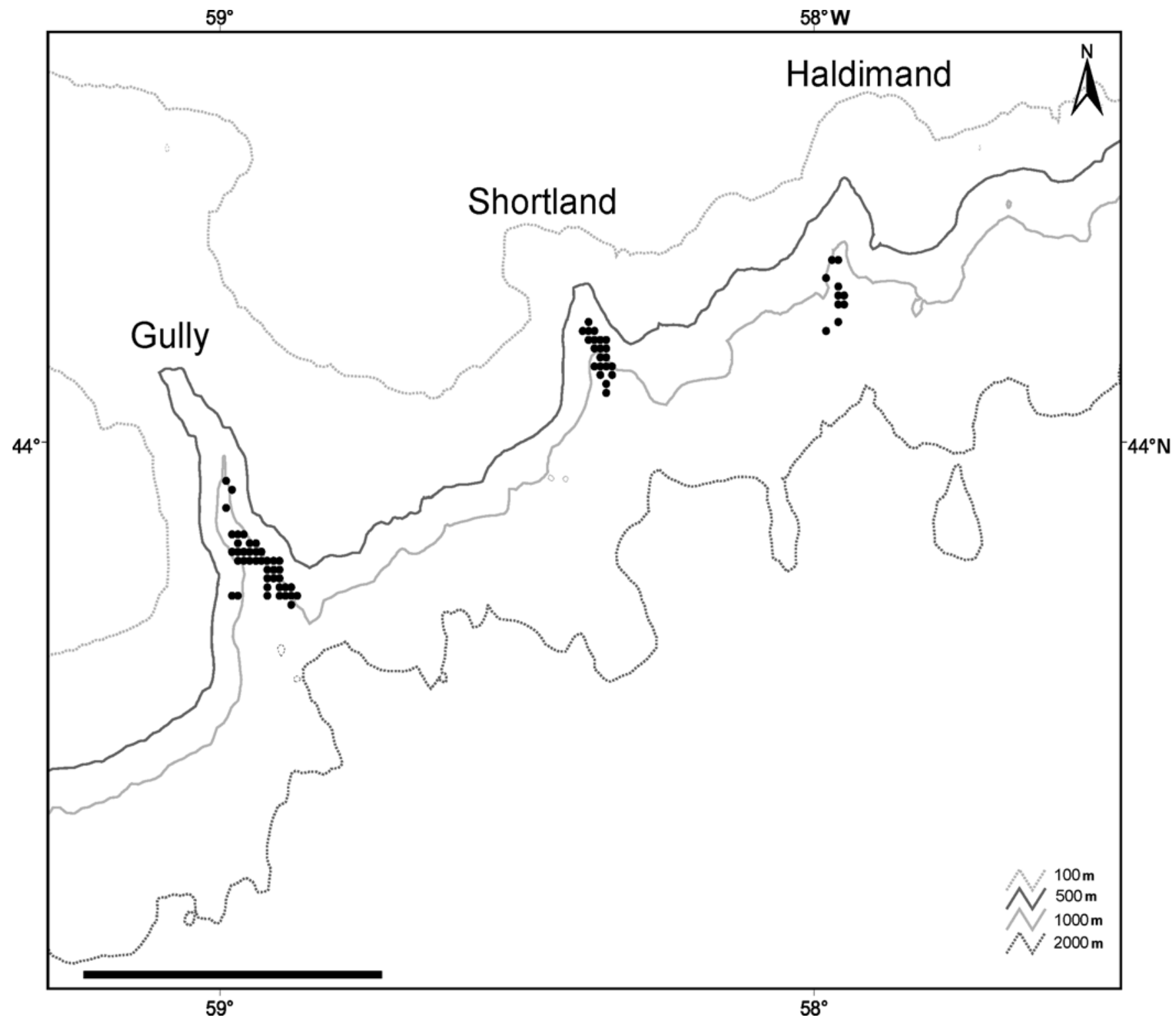

Table 3. Rates of encounter with northern bottlenose whales in the Gully for 1988-1998 (Hooker et al. $2002 b$ ) and in the Gully and Shortland and Haldimand canyons during good weather conditions in 2001 and 2002, together with water depths at encounter locations in 1988-1998 and 2002.

\begin{tabular}{lllll}
\hline & $\begin{array}{l}\text { No. of } \\
\text { search hours }\end{array}$ & $\begin{array}{l}\text { No. of } \\
\text { encounters }\end{array}$ & $\begin{array}{l}\text { No. of } \\
\text { encounters/h }\end{array}$ & $\begin{array}{l}\text { Water } \\
\text { depth }(\mathrm{m})^{a}\end{array}$ \\
\hline $\begin{array}{l}\text { 1988-1998 } \\
\text { The Gully } \\
\begin{array}{l}\text { 2001/2002 } \\
\text { The Gully }\end{array}\end{array}$ & 1446 & 715 & 0.494 & $1200(300)$ \\
$\quad \begin{array}{l}\text { Shortland canyon } \\
\text { Haldimand canyon }\end{array}$ & 94 & 51 & 0.541 & $1162(260)$ \\
\end{tabular}

\footnotetext{
${ }^{a}$ Values are given as the mean with SD in parentheses.
}

whales in the Gully and Shortland and Haldimand canyons from 1988 to 2002. The majority of the sightings were at depths greater than $800 \mathrm{~m}$.
Population structure and movements of northern bottlenose whales on the Scotian Slope

Of the 67 reliably marked individuals photographed in 
Fig. 5. Northern bottlenose whale sightings from 1988 to 2002 in the Gully and Shortland and Haldimand canyons (Hooker et al. 1999, 2002b; unpublished data from H. Whitehead's laboratory; Wimmer 2003). The scale bar represents $35 \mathrm{~km}$.

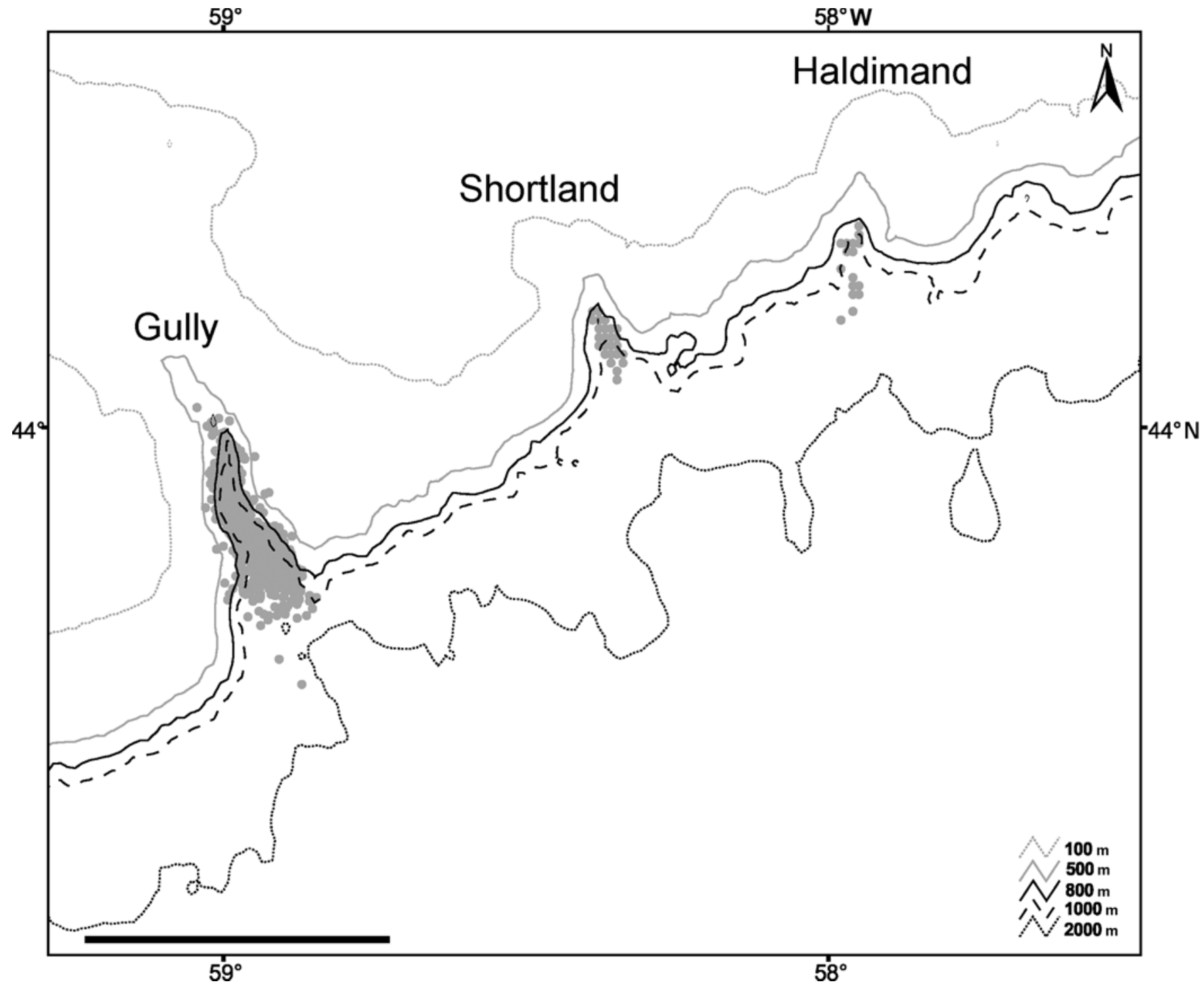

Table 4. Total number of reliably identified female, subadult male, and mature male northern bottlenose whales observed within each canyon in 2001/2002.

\begin{tabular}{llll}
\hline Canyon & $\begin{array}{l}\text { Females / } \\
\text { immature males }\end{array}$ & $\begin{array}{l}\text { Subadult } \\
\text { males }\end{array}$ & $\begin{array}{l}\text { Mature } \\
\text { males }\end{array}$ \\
\hline Gully & 10 & 5 & 11 \\
Shortland & 5 & 2 & 3 \\
Haldimand & 3 & 2 & 7 \\
\hline
\end{tabular}

Shortland and Haldimand canyons in 2001 and 2002, 26 (39\%) had been photographed in the Gully in earlier years. This is a significantly smaller proportion than the 34 of 57 $(60 \%)$ of the reliably identified individuals in the Gully in $2001 / 2002$ that had previously been identified there ( $G$ test, $G=5.358, p=0.021$ ). Thus, the northern bottlenose whales previously identified in the Gully are not fully mixing between the three canyons over time scales of at least 2 years, so individuals seem to have preferences for particular can- yons. In contrast, proportions of the three age-sex classes were similar in the three canyons (Table $4 ; G$ test, $G=$ $1.990, p=0.738$ ).

During each of the 2001 and 2002 field seasons, identified individuals were observed to move between canyons (Table 5). The emigration and re-immigration model best described the residence times of northern bottlenose whales in the three canyons as indicated by LIRs (Table 6). This indicates that within a summer season, whales may enter, leave, and reenter any of the three canyons. It was estimated that the whales spent a mean of 22 days within any given canyon before leaving (Table 6). The data set used for this analysis contained the data from the Gully in 1988-1999 used by Gowans et al. (2000b), therefore the residence times within canyons (22 days) in this study are similar to the residence times within the Gully (20 days) that they found. The estimated mean interval between exit and reentry was too imprecise to be useful.

The two models of interchange between canyons fit about equally well (Table 6) and are both shown in Fig. 6. They in- 
Table 5. Numbers of photo-identified individuals in the three canyons in 2001 and 2002 (from photographs of the left and right sides of the dorsal fin) and the numbers of these that were reidentified on a different day within the same and other canyons in the same year.

\begin{tabular}{|c|c|c|c|c|c|}
\hline & \multicolumn{2}{|c|}{ No. of identifications from: } & \multicolumn{3}{|c|}{ Also identified in: } \\
\hline & Left side & Right side & The Gully & $\begin{array}{l}\text { Shortland } \\
\text { canyon }\end{array}$ & $\begin{array}{l}\text { Haldimand } \\
\text { canyon }\end{array}$ \\
\hline \multicolumn{6}{|l|}{2001} \\
\hline The Gully & 45 & 36 & 4 & 0 & 1 \\
\hline Shortland canyon & 6 & 6 & 0 & 0 & 5 \\
\hline Haldimand canyon & 24 & 27 & 1 & 5 & 0 \\
\hline \multicolumn{6}{|l|}{2002} \\
\hline The Gully & 54 & 53 & 19 & 3 & 4 \\
\hline Shortland canyon & 41 & 45 & 3 & 15 & 5 \\
\hline Haldimand canyon & 11 & 13 & 4 & 5 & 0 \\
\hline
\end{tabular}

Table 6. Models fit to lagged identification rates for within-canyon residence times and between-canyon movements of all identified individuals within summer seasons.

\begin{tabular}{|c|c|c|c|c|}
\hline $\begin{array}{l}\text { Model } \\
\text { No. }\end{array}$ & Model description & $\begin{array}{l}\text { Maximum-likelihood value for } \\
\text { parameters }\end{array}$ & $\begin{array}{l}\text { Bootstrapped SEs } \\
\text { for parameters }\end{array}$ & $\begin{array}{l}\text { Summed log-likelihood } \\
\text { for model }\end{array}$ \\
\hline \multicolumn{5}{|c|}{ Residence within canyons } \\
\hline \multirow[t]{2}{*}{2} & Emigration & $N=83.5$ individuals & 4.80 & -12323.2 \\
\hline & & Mean residence time $=39.1$ days & 4.10 & \\
\hline 3 & Emigration and re-immigration & $N=74.1$ individuals & 4.60 & -12311.1 \\
\hline \multicolumn{5}{|c|}{ Movements between canyons } \\
\hline 4 & Fully mixed & $N=762.3$ individuals & 179.80 & -160.3 \\
\hline \multirow[t]{2}{*}{5} & Migration - full interchange & $N=716.2$ individuals & 172.10 & -159.7 \\
\hline & & Residence time in $=1.3$ days & 0.40 & \\
\hline
\end{tabular}

dicate that at least some individuals are moving between the three canyons (Table 6). The migration - full interchange model estimated that individuals spent only 1.3 days within a canyon before moving to another, much less than the 22.0 days estimated by the within-canyon model. The discrepancy can be explained by heterogeneity in movement: some animals remain within particular canyons for long periods, and others, those considered in the between-canyon models, quite frequently move between them. The estimate of population size from this model (716) is inaccurate for this and other reasons.

Figure 6 shows the best-fit models of LIRs for both residence times within and movements between canyons. The best-fit line for residence times within canyons lies well above the best-fit lines for movements between. In a fully mixed population, the two lines from the two kinds of models would converge to a common asymptote. That they do not is another indication that there is heterogeneity in movement patterns.

Similar analyses of the data on within-canyon residency for each sex separately suggested that females / immature males spent longer within canyons before emigrating (mean $=39.9$ days, $\mathrm{SE}=6.1$ days) than did mature or maturing males $($ mean $=16.6$ days, $\mathrm{SE}=7.2$ days). Because data were few, the LIRs for movement between canyons by males and females separately could not be examined. However, upon examination of the raw data it appears that males moved more frequently between canyons than did females. Seven of the 17 reliably marked males, but only 1 of the 16 reliably marked females, identified in 2001 or 2002 were resighted within different canyons during the same field season. The time between reidentifications in different canyons for the single female was 9 days, whereas the mean time between reidentifications of males was 4.3 days. When the 2001 and 2002 field seasons are combined, once again males seemed to move more between canyons more than did females: 11 of the 17 males were identified in more than one canyon versus 2 of the 16 females.

Estimated transition probabilities for movement between the Gully, Shortland and Haldimand canyons, and an external area are shown in Table 7. SEs of transition probabilities are fairly large, owing to the small number of resightings of individuals between canyons, therefore the estimated transition rates should be viewed with caution. After 1 day, individuals are more likely to be still in the same area than to have moved to another (Table 7). Rates of movement to new areas are lowest for the Gully, but movement possibilities are indicated between all pairs of canyons and the external area.

\section{Discussion}

\section{Distribution}

The main focus of this work was to address the question of where northern bottlenose whales go when they leave the 
Fig. 6. Lagged identification rates (probability of reidentifying an animal in a different canyon after a certain time lag) for northern bottlenose whales within and between the Gully and Shortland and Haldimand canyons. Best-fit models (based on likelihood methods) for within-canyon residence and between-canyon movement are also shown. The vertical lines are bootstrap estimates of SE.

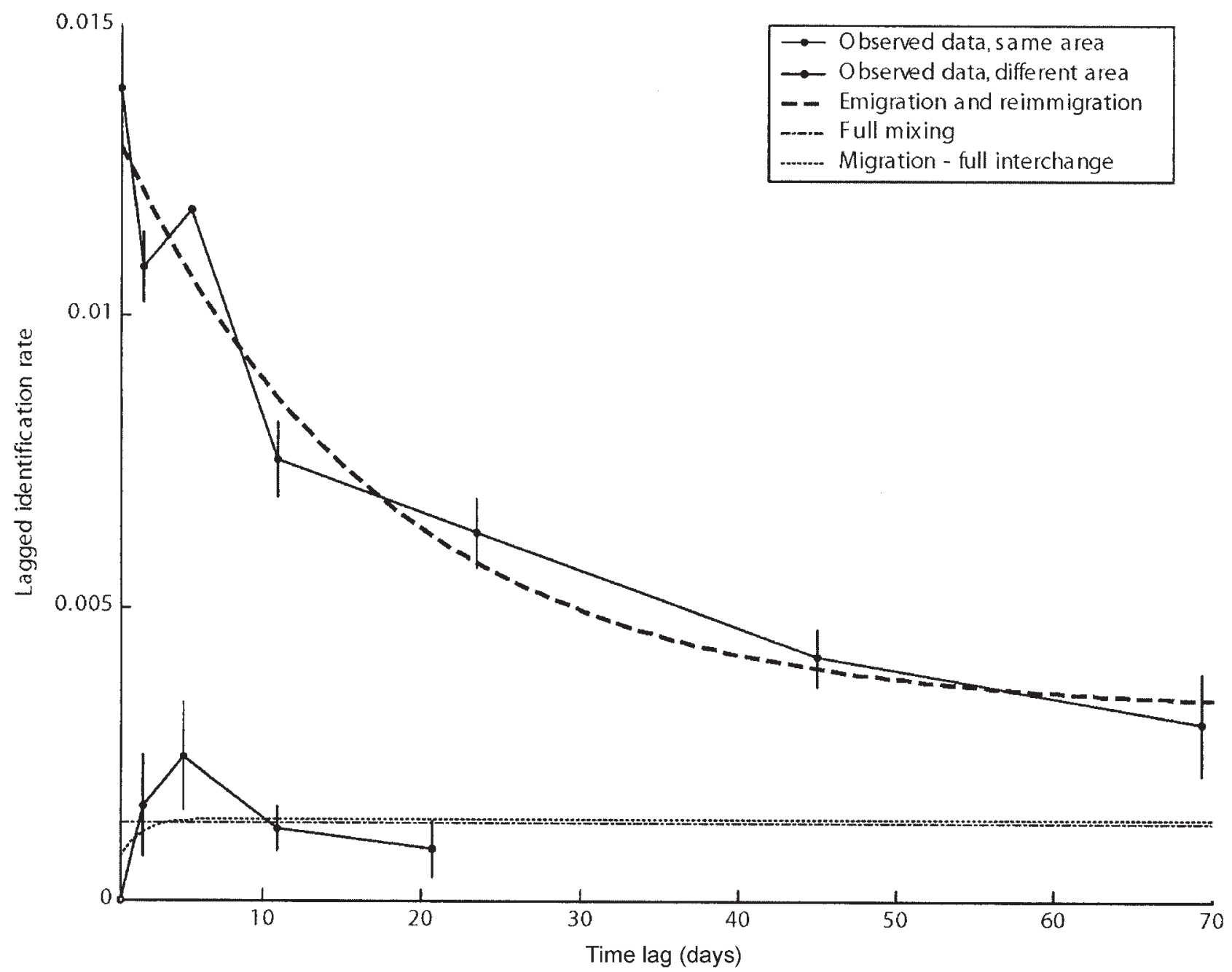

Table 7. Probabilities of individuals moving in 1 day between the Gully and Shortland and Haldimand canyons and an external area.

\begin{tabular}{lllll}
\hline & To the Gully & To Shortland canyon & To Haldimand canyon & Out \\
\hline From the Gully & 0.916 & $0.0001(0.006)$ & $0.083(0.036)$ & $0.0009(0.036)$ \\
From Shortland canyon & $0.0000(0.043)$ & 0.7578 & $0.000(0.048)$ & $0.2422(0.087)$ \\
From Haldimand canyon & $0.1322(0.064)$ & $0.1665(0.070)$ & 0.3524 & $0.3489(0.076)$ \\
Out & $0.1368(0.107)$ & $0.1111(0.111)$ & $0.0874(0.112)$ & 0.6647 \\
\hline
\end{tabular}

Note: Values in parentheses are bootstrap estimates of SE.

Gully. This question has been at least partially answered with the discovery that Gully northern bottlenose whales use Shortland and Haldimand canyons. Although there have been several sightings of northern bottlenose whales in other areas on and surrounding the Scotian Slope (Fig. 1), the only areas in which we know they can be reliably found are the Gully and Shortland and Haldimand canyons.

This canyon-centred distribution is both unusual and interesting. Over the southern part of the study area, Kenney and Winn (1987) found no significant increase in cetacean biomass in canyons, and in the nearest other northern bottlenose whale habitat, off northern Labrador and in the Davis Strait, the whales' distribution is not obviously centred on canyons
(Benjaminsen and Christensen 1979). The contrast may be explained by the size of the canyons on the eastern Scotian Shelf. The canyons in this area, especially the Gully, are substantially larger than those of the northeastern USA or northern Labrador, and large canyons seem likely to have a disproportionate effect on oceanographic processes (e.g., see Hickey 1997; Allen et al. 2001). That the Gully possesses a higher density of northern bottlenose whales than the smaller Haldimand and Shortland canyons is further evidence that larger canyons have a disproportionate oceanographic influence.

Encounter rates in Shortland and Haldimand canyons clearly show that these areas are used fairly regularly by 
northern bottlenose whales, although to a lesser extent than the Gully. The whales in the three canyons have similar sex ratios (Table 4), use similar depths (Table 3), and seemed to be behaving similarly (personal observations). Thus, the reasons for their presence in the three canyons are likely similar. So, following Hooker et al.'s (2002a) discussions of the ecology of the northern bottlenose whales in the Gully, we expect that they are primarily present in Haldimand and Shortland canyons because of enhanced abundance of their prey, probably principally the squid Gonatus steenstrupi Kristensen, 1981. However, why these squid should concentrate in the canyons is not clear. Speculations include enhancement of their benthic food sources, or the formation of mating aggregations (see Hooker et al. 2002a).

\section{Movements between canyons}

Northern bottlenose whales do move between the three canyons. The function of this movement can be considered from the perspective of optimal foraging on dispersed patches of prey. As the Gully (the richer patch) fills with more northern bottlenose whales, individuals would likely do better in terms of individual net gain to use other, albeit poorer, areas with fewer competitors (Haldimand and Shortland canyons and other areas). An ideal free distribution (IFD) then results, in which animals in all prey patches have similar feeding success (Fretwell and Lucas 1970). Even under an IFD, movement of individuals between areas has been reported after equilibrium has been reached (see review in Hugie and Grand 1998). An IFD assumes that individuals have perfect knowledge of the availability of resources in the environment. However, it is unlikely that individuals do have perfect knowledge and thus they may be moving to gain information on the surrounding habitat ("sampling") or for other reasons. Movement between canyons could thus reflect such sampling.

While males and females seem to use the canyons in similar proportions, there are differences in the movement patterns of the sexes. Males appear to remain in canyons for shorter periods and to move between canyons more frequently than females. In many mammal populations, movements of females are related to location of prey patches and areas that provide adequate protection from predators, while movement of males is related to access to females (Davies 1991). Clutton-Brock (1989) suggests that where females range widely and live in small groups, males may rove in search of estrous females. It is therefore likely that female northern bottlenose whales are distributing themselves in relation to prey within the canyons, while males are moving between canyons to increase their mating opportunities. The different rates of movement for male and female northern bottlenose whales may reflect differences in the dynamics of the resources that drive the formation of their distributions. It is likely that the relative abundance of deep-water squid changes more slowly than that of receptive females, and thus males may need to sample more than females do and so move more frequently. Additionally, local knowledge is likely more important when the primary resource is food than when it is mates, promoting greater site fidelity among females.

The pattern of greater movement by males is common among mammals (ungulates, Ruckstuhl and Neuhaus 2001; elephants, Barnes 1982; Wrangham and Rubenstein 1986), including the only other member of the Ziphiidae for which data on this topic have been analyzed: Durban et al. (2001) found that female densebeak whales (Mesoplodon densirostris (Blainville, 1817)) exhibited a higher degree of site fidelity than males in the waters off the Bahamas.

\section{Scale of movements}

Scotian Shelf northern bottlenose whales do not appear to undergo seasonal migrations; they are thought to inhabit the Gully year-round. In addition to the summer, there have been sightings of northern bottlenose whales in the Gully and on the Scotian Shelf during the spring, fall, and winter months (Reeves et al. 1993). Movements within the Gully are on the scale of $4-5 \mathrm{~km}$ daily within a range encompassing 15-30 $\mathrm{km}^{2}$ (Hooker et al. 2002b). Movements on the Scotian Shelf for the majority of individuals appear to be on the scale of only 50-100 km over several days; some animals have preferences among the three canyons at a scale of about $100 \mathrm{~km}$; and there are genetic differences between the animals on the Scotian Shelf and those $1300 \mathrm{~km}$ north, off Labrador (Dalebout et al. 2001).

Thus, daily movements of the Scotian Shelf northern bottlenose whales are on the order of a few kilometres, and their home ranges a few hundred kilometres or less. Compared with other large pelagic species, these are relatively small displacements (Whitehead 2003). Sperm whales (Physeter macrocephalus L., 1758) in the South Pacific Ocean inhabit areas on the order of 1000-3000 km across, and appear to move about $70 \mathrm{~km}$ daily (Whitehead 2003). Large seals also move widely, with northern elephant seals (Mirounga angustirostris (Gill, 1866)) displacing 73$103 \mathrm{~km}$ /day and possessing home ranges spanning $4500 \mathrm{~km}$ (Stewart and DeLong 1995). Tunas (Thunnus South, 1845) and billfishes (Istiophoridae) travel 26-65 km/day, their home ranges spanning $3000-10000 \mathrm{~km}$ (Joseph et al. 1988).

The movements of northern bottlenose whales appear to be more similar to the movements of coastal dolphins and porpoises. Harbour porpoises (Phocoena phocoena L., 1758) tagged in the Gulf of Maine had daily movements ranging from 14 to $28 \mathrm{~km}$ (Read and Westgate 1997). Movements of bottlenose dolphins (Tursiops truncatus (Montagu, 1821)) tagged with satellite tags in Tampa Bay, Florida, were on the order of $25 \mathrm{~km} /$ day (Mate et al. 1995).

This lack of movement of northern bottlenose whale may be related to the types of prey they exploit. Whitehead et al. (2003) concluded that differences in niche breadth of mesopelagic teuthivores may be closely related to their movement patterns. They found that sperm whales and elephant seals (Mirounga Gray, 1827), which travel great distances and thus may encounter the greatest variety of squid species, have the widest niche breadths. Northern bottlenose whales, which have very localized movements and specialize on Gonatus spp., have a very narrow niche breadth. It is not known whether prey specialization causes localized movements or vice versa (Whitehead et al. 2003).

\section{Conservation implications}

As noted earlier, the Scotian Slope population of northern bottlenose whales is of considerable conservation interest. 
The results presented in this paper have important consequences for efforts to protect this population.

First, and on the positive side, the lack of full mixing over periods of years between the northern bottlenose whales in the Gully and in the other two canyons has implications for population estimation. The estimate of 130 animals calculated using mark-recapture methods on Gully photoidentifications (Gowans et al. 2000b) is likely to be something of an underestimate of the entire Scotian Slope population. More sophisticated mark-recapture methods that include spatial heterogeneity should be used to update the population estimate, especially after additional identifications have been collected from all three canyons. However, as the Gully is certainly the principal habitat for this population, and many animals move between the canyons, the increase in estimated numbers following such an analysis is not likely to be very large.

Secondly, and more significantly, it is very clear that Shortland and Haldimand canyons are important to this endangered population. Figure 5 shows that Scotian Shelf northern bottlenose whales are typically found in waters deeper than $800 \mathrm{~m}$ and thus these areas may be considered critical habitat for this endangered species. Given the increase in human activities on the Scotian Slope, particularly oil and gas exploration, it is crucial that they are protected. Currently, only the Gully is protected, as it is designated a Marine Protected Area (http://www.mar.dfo-mpo.gc.ca). During the summer of 2003, seismic was shot on a lease located $10.6 \mathrm{~km}$ southwest of the northern bottlenose whales' primary habitat in the Gully (Moulton et al. 2003) and on another lease $10 \mathrm{~km}$ east of their distribution in Haldimand canyon (M. Thillet, personal communication). The effects of seismic on northern bottlenose whales are unknown, but there are reasons for concern both on theoretical grounds (Houser et al. 2001) and because of the known ability of loud sounds to kill members of other beaked whale species (e.g., Jepson et al. 2003). Another threat to northern bottlenose whales is entanglement in longline fishing gear (Gowans et al. 2000b). The longline fishery is primarily for swordfish and is concentrated close to the Scotian Shelf break in deep water, including the deeper waters of the Gully and Shortland and Haldimand canyons. While designation of the Gully as a Marine Protected Area will lead to the removal of this gear from the prime habitat of the northern bottlenose whales (Canada Gazette 2003), they will still be vulnerable in the other canyons.

\section{Acknowledgments}

Our fieldwork and analysis were funded by World Wildlife Fund (WWF) Canada - Environment Canada Endangered Species Recovery Fund, the Natural Sciences and Engineering Research Council of Canada (NSERC), the Canadian Whale Institute, the Island Foundation, and the Department of Fisheries and Oceans. T. Wimmer was supported by a NSERC Graduate Scholarship, the Patrick Lett Fund, and S. Haney. Thanks are extended to L. Rendell for skippering the research vessel; all the crew members of Balaena; those who provided data on sightings of northern bottlenose whales and bathymetry data; staff at WWF Atlantic for providing depth files and technical support; A. Reid and
J. Boxall for help in preparing figures; P. Clapham, Sascha Hooker, and the NMFS team for contributing data; M. Auger-Méthé and D. Crowel for help with the photoidentification analysis; and P. Clapham, S. Gowans, R. Kenney A. Metaxas, R. Rangely, A. Reid, S.C. Smith, and an anonymous reviewer for comments on versions of the manuscript.

\section{References}

Allen, S.E., Vindeirinho, C., Thomson, R.E., Foreman, M.G.G., and Mackas, D.L. 2001. Physical and biological processes over a submarine canyon during an upwelling event. Can. J. Fish. Aquat. Sci. 58: 671-684.

Barnes, R.F.W. 1982. Mate searching behavior of elephant bulls in a semi-arid environment. Anim. Behav. 30: 1217-1223.

Benjaminsen, T., and Christensen, I. 1979. The natural history of the bottlenose whale, Hyperoodon ampullatus (Forster). In Behaviour of marine animals: current perspectives in research. Edited by H.E. Winn and B.L. Olla. Plenum Press, New York and London. pp. 143-164.

Bjørke, H. 2001. Predators of the squid Gonatus fabricii (Lichtenstein) in the Norwegian Sea. Fish. Res. 52: 113-120.

Canada Gazette. 2003. Gully Marine Protected Area regulations. Available at http://canadagazette.gc.ca/partI/2003/20031206/html/ regle1-e.html [accessed 8 January 2004].

Canada - Nova Scotia Offshore Petroleum Board. 2004. Available at www.cnsopb.ns.ca [accessed 24 October 2004].

Cetacean and Turtle Assessment Program.1982. A characterization of marine mammals and turtles in the Mid- and North-Atlantic areas of the U.S. outer continental shelf. Contract AA551-CT848, Bureau of Land Management, Department of the Interior, Washington, D.C.

Clutton-Brock, T.H. 1989. Mammalian mating systems. Proc. R. Soc. Lond. B Biol. Sci. 236: 339-372.

Committee on the Status of Endangered Wildlife in Canada. 2002. COSEWIC status assessments, November 2002. Northern Bottlenose Whale. Committee on the Status of Endangered Wildlife in Canada, Ottawa, Ont. Available at http://www.cosewic.gc.ca [accessed 5 January 2004].

Dalebout, M.L., Hooker, S.K., and Christensen, I. 2001. Genetic diversity and population structure among northern bottlenose whales, Hyperoodon ampullatus, in the western north Atlantic Ocean. Can. J. Zool. 79: 478-484.

Davies, N.B. 1991. Mating systems. In Behavioural ecology: an evolutionary approach. Edited by J.R. Krebs and N.B. Davies. Blackwell Scientific Publications, Oxford. pp. 263-294.

Durban, J., Claridge, D., Parsons, K., Ellifrit, D., and Balcomb, K. 2001. Quantifying beaked whale occupancy: resident females and roving males. In Abstracts from the Workshop on the Biology and Conservation of Beaked Whales, 14th Biennial Conference on the Biology of Marine Mammals, Vancouver, B.C., 28 November 2001. p. 21.

Fretwell, S.D., and Lucas, H.L. 1970. On territorial behavior and other factors influencing habitat distribution in birds. Acta Biotheor. 19: 1-39.

Gowans, S., and Whitehead, H. 2001. Photographic identification of northern bottlenose whales (Hyperoodon ampullatus): sources of heterogeneity from natural marks. Mar. Mamm. Sci. 17: 7693.

Gowans, S., Dalebout, M.L., Hooker, S.K., and Whitehead, H. $2000 \mathrm{a}$. Reliability of photographic and molecular techniques for 
sexing northern bottlenose whales (Hyperoodon ampullatus). Can. J. Zool. 78: 1224-1229.

Gowans, S., Whitehead, H., Arch, J.K., and Hooker, S.K. $2000 b$. Population size and residency patterns of northern bottlenose whales (Hyperoodon ampullatus) using the Gully, Nova Scotia. J. Cetacean Res. Manag. 2: 201-210.

Gray, D. 1882. Notes on the characters and habits of the bottlenose whale (Hyperoodon rostratus). Proc. Zool. Soc. Lond. 1882: 726-731.

Hickey, B.M. 1997. The response of a steep-sided narrow canyon to strong wind forcing. J. Phys. Oceanogr. 27: 697-726.

Hooker, S.K. 1999. Resource and habitat use of northern bottlenose whales in the Gully: ecology, diving and ranging behaviour. Ph.D. dissertation, Dalhousie University, Halifax, N.S.

Hooker, S.K., Whitehead, H., and Gowans, S. 1999. Marine protected area design and the spatial and temporal distribution of cetaceans in a submarine canyon. Conserv. Biol. 13: 592-602.

Hooker, S.K., Whitehead, H., and Gowans, S. 2002a. Ecosystem consideration in conservation planning: energy demand of foraging bottlenose whales (Hyperoodon ampullatus) in a marine protected area. Biol. Conserv. 104: 51-58.

Hooker, S.K., Whitehead, H., Gowans, S., and Baird, R.W. $2002 b$. Fluctuations in the distribution and patterns of individual range use of northern bottlenose whales. Mar. Ecol. Prog. Ser. 225: 287-297.

Houser, D.S., Howard, R., and Ridgway, S. 2001. Can divinginduced tissue nitrogen supersaturation increase the chance of acoustically driven bubble growth in marine mammals? J. Theor. Biol. 213: 183-195.

Hugie, D.M., and Grand, T.C. 1998. Movement between patches, unequal competitors and the ideal free distribution. Evol. Ecol. 12: $1-19$.

International Whaling Commission. 2004. Report of the standing working group on environmental concerns. Annex K. Report of Scientific Committee of International Whaling Commission. The International Whaling Commission, Cambridge, UK. Available at http://www.iwcoffice.org [accessed on 24 October 2004].

Jepson, P.D., Arbelo, M., Deaville, R., Patterson, I.A.R., Castro, P., Baker, J.R., et al. 2003. Gas-bubble lesions in stranded cetaceans. Nature (Lond.), 425: 575-576.

Joseph, J., Klawe, W., and Murphy, P. 1988. Tuna and billfish: fish without a country. Inter-American Tropical Tuna Commission, La Jolla, Calif.

Kenney, R.D., and Winn, H.E. 1987. Cetacean biomass densities near submarine canyons compared to adjacent shelf/slope areas. Cont. Shelf Res. 7: 107-114.

Mate, B.R., Rossback, K.A., Nieukirk, R.L., Wells, R.S., Irvine, A.B., Scott, M.D., and Read, A.J. 1995. Satellite-monitored movements and dive behaviour of a bottlenose dolphin (Tursiops truncatus) in Tampa Bay, Florida. Mar. Mamm. Sci. 11: 452463.
Moulton, V.D., Davis, R.A., Cook, J.A., Austin, M., Reece, M.L., Martin, S.A., et al. 2003. Environmental assessment of Marathon Canada Limited's 3-D seismic program on the Scotian Slope, 2003. LGL Rep. SA744-1, LGL Ltd., St. John's, N.L., for Marathon Canada Ltd., Halifax, N.S.

O'Corry-Crowe, G.M., Suydam, R.S., Rosenberg, A., Frost, K.J., and Dizon, A.E. 1997. Phylogeography, population structure and dispersal patterns of the beluga whale Delphinapterus leucas in the western Nearctic revealed by mitochondrial DNA. Mol. Ecol. 6: 955-970.

Read, A.J., and Westgate, A.J. 1997. Monitoring the movements of harbour porpoises (Phocena phocena) with satellite telemetry. Mar. Biol. (Berl.) 130: 315-322.

Reeves, R., Mitchell, E., and Whitehead, H. 1993. Status of the northern bottlenose whale, Hyperoodon ampullatus. Can. FieldNat. 107: 490-508.

Ruckstuhl, K.E., and Neuhaus, P. 2001. Behavioral synchrony in ibex groups: effects of age, sex and habitat. Behaviour, 138: 1033-1046.

Stewart, B.S., and DeLong, R.L. 1995. Double migrations of the northern elephant seal, Mirounga angustirostris. J. Mammal. 76: 196-205.

Turchin, P. 1998. Quantitative analysis of movement. Sinauer Associates, Inc., Sunderland, Mass.

Waring, G.T., Quintal, J., and Fairfield, C.P. (Editors). 2002. U.S. Atlantic and Gulf of Mexico marine mammal stock assessments - 2002. NOAA Tech. Mem. NMFS-NE-169.

Whitehead, H. 2001. Analysis of animal movement using opportunistic individual identifications: application to sperm whales. Ecology, 82: 1417-1432.

Whitehead, H. 2003. Sperm whale: social evolution in the ocean. University of Chicago Press, Chicago.

Whitehead, H. 2004. SOCPROG version 2.0 for MATLAB version 6.5 [computer program]. Available from http://myweb.dal.ca/ hwhitehe/social.htm [accessed 10 May 2003].

Whitehead, H., Faucher, A., Gowans, S., and McCarrey, S. 1997. Status of the northern bottlenose whale, Hyperoodon ampullatus, in the Gully, Nova Scotia. Can. Field-Nat. 111: 287-292.

Whitehead, H., MacLeod, C.D., and Rodhouse, P. 2003. Differences in niche breadth among some teuthivorous mesopelagic marine mammals. Mar. Mamm. Sci. 19: 400-406.

Wimmer, T. 2003. Distribution of cetaceans on the continental shelf break off Nova Scotia and in adjacent waters with a focus on northern bottlenose whales, Hyperoodon ampullatus. M.Sc. thesis, Dalhousie University, Halifax, N.S.

Wrangham, R.W., and Rubenstein, D.I. 1986. Social evolution in birds and mammals. In Ecological aspects of social evolution. Edited by R. Wrangham. Princeton University Press, Princeton, N.J. pp. 452-471. 